\title{
Growth responses of potted chrysanthemum "Armita Agrihorti" variety at various concentration of bio-urine liquid fertilizer
}

\author{
Yuniarti ${ }^{*}$, Rika Meilasari, and Firmansyah Aznur \\ Assessment Institute for Agricultural Technology West Sumatera, Jalan Raya Padang - Solok Km.40 \\ Sukarami, Kab. Solok. West Sumatera, Indonesia. PO Box 34 Padang
}

\begin{abstract}
Nutrients are needed to increase crop production. Liquid fertilizer (bio-urine), which macro elements, easily absorbed by plants and quickly shows results with optimum concentration, is one of the organic fertilizers that can be used as a trigger for the growth of potted chrysanthemums. The aim of this study to determine the optimum concentration of bio-urine in potted chrysanthemum cultivation. This research was conducted from October to December 2020 at West Sumatera AIAT's greenhouse on altitude of $1000 \mathrm{~m}$ above sea level, was designed with a Randomized Complete Block Design and five replications. Observed consist of five concentrations of bio-urine, namely (1) $200 \mathrm{ml} \mathrm{L}^{-1}$ of water, (2) $100 \mathrm{ml} \mathrm{L}^{-1}$ of water, (3) $66.67 \mathrm{ml} \mathrm{L}^{-1}$ of water, (4) $50 \mathrm{ml} \mathrm{L}^{-1}$ and (5) 40 $\mathrm{ml} \mathrm{L}^{-1}$ of water. Parameters observed were plant height, number and length of internodes, number of branches, stem diameter, flower initiation, number and diameter of flowers, and petiole length. The result shows that Bio-urine with a concentration of $100 \mathrm{ml} \mathrm{L}^{-1}$ of water produces potted chrysanthemum with optimum parameters of plant height, number of internodes, number of branches, stem diameter, number of flowers, flower diameter, and petiole length.
\end{abstract}

\section{Introduction}

Chrysanthemum is an ornamental plant that have the potential to be developed either as cut flowers or pots. The high demand for ornamental plants, both from flower production and seeds marketed domestically and abroad, is a business opportunity for ornamental plant production centers in Indonesia. The high demand for ornamental plants leads the business of procuring ornamental plants promising big profits, one of the popular ornamental plants is the chrysanthemum. In Indonesia, the demand for chrysanthemums is increasing by $25 \%$ per year. So far, Indonesia is still importing chrysanthemum seeds from abroad, especially the Netherlands, Germany, America, and Japan. The latest data from the Central Statistics Agency show that in 2019 the production of chrysanthemum plants in Indonesia was the highest compared to other ornamental plants, 465,359,952 pcs [1].

Availability of nutrients is needed in increasing crop production. Potted chrysanthemums need the addition of nutrients in the form of fertilizers. The use of organic fertilizers is an

* Corresponding author: yuniartiir@yahoo.com 
alternative in potted chrysanthemum cultivation. In addition to providing nutrients, it can also act as soil organic matter. The application of organic fertilizers to cultivated plants can increase soil productivity and improve the soil's chemical, physical and biological properties [2]. The results of previous research [3] showed that the application of 20 tons of cow manure was able to increase plant height and stem diameter of chrysanthemum compared to the use of chicken manure. The application of cow manure had a good effect only on plant height at the age of 14 and 28 days after planting (DAP), the number of leaves at 42 DAP, and flower diameter of $2 \mathrm{~kg} \mathrm{~m}^{-2}$ [4].

Another organic fertilizer that can be used is liquid organic fertilizer (Bio-urine) which contains rich in macro elements and is easily absorbed by plants and shows results quickly, with the right concentration being one of the organic fertilizers that can be used as a trigger for the growth of potted chrysanthemums. According to Sitorus et al. [5], Sheep bio urine can be used as a source of liquid organic fertilizer, because it is high containing $\mathrm{N}$ and $\mathrm{K}$, and as well as hormones for plant growth. The use of sheep bio urine on chrysanthemum (Dendranthema grandiflora Tzvelev) effect plant height, leaf width, and flower quality [6]. Another study [7], showed that the combination of bio urine treatment, inorganic fertilizer $25 \%$ of the recommended dose, and cow manure $25 \%$ of the recommended dose, gave the highest yield on shallots, amounting to 6.09 tons ha-1. Therefore, this study was designed to determine the optimum concentration of Bio-urine Liquid Organic Fertilizer (LOF) in potted chrysanthemum cultivation.

\section{Materials and methods}

This research was conducted from October to December 2020 at the West Sumatra AIAT Greenhouse at an altitude of $1000 \mathrm{~m}$ above sea level, was designed with a Randomized Complete Block Design and five replications. The observed variables were consisting of five concentrations of LOF, namely (1) $200 \mathrm{ml} \mathrm{L}^{-1}$ of water, (2) $100 \mathrm{ml} \mathrm{L}^{-1}$ of water, (3) $66.67 \mathrm{ml}$ $\mathrm{L}^{-1}$ of water, (4) $50 \mathrm{ml} \mathrm{L}^{-1}$ of water dan (5) $40 \mathrm{ml} \mathrm{L}^{-1}$ of water. Each pot was given $200 \mathrm{ml}$ of LOF solution.

The used chrysanthemum seeds were rooted cuttings, planted in plastic pots with a diameter of $17 \mathrm{~cm}$. The planting medium used was a mixture of soil + compost + husk charcoal with a ratio of $2: 1: 1$. In each pot, five chrysanthemum cuttings were planted. Giving long days is done up to 18 days after planting (DAP). At 8 DAP, pinching or removal of the apical bud was carried out to stimulate the growth of lateral branches. Watering is done 2-3 times a week. Prevention of plant pests and diseases is done by spraying fungicides and insecticides once a week [8]. Liquid organic fertilizer treatment is carried out two times a week starting from 14 DAP. The dosage of bio-urine liquid organic fertilizer used is based on each treatment concentration of fertilization. Fertilization is done by pouring the LOF into the planting medium surrounding the plants.

Observations were made at harvesting time, approximately at 64 DAP. Parameters observed included plant height, number of internodes, number of branches, stem diameter, flower initiation, number of flowers, and flower diameter. The research data were analyzed using an analysis of variance. If there is a significant difference between the treatments, further testing is performed using the Duncan Multiple Range Test with a level of 5\%.

\section{Results and discussion}

The analysis of variance showed significant differences in agronomic characters of potted chrysanthemum to different treatments of bio urine concentration tested, except for the flower initiation parameter (Table 1). 
Table 1. Analysis of variance of different traits of potted chrysanthemum to LOF bio-urine treatment at various concentrations.

\begin{tabular}{ll}
\hline Parameter & $\begin{array}{l}\text { Treatment } \\
\text { Bio-urine Concentration }\end{array}$ \\
\hline Plant height $(\mathrm{cm})$ & $5.22 * *$ \\
Number of internodes & $5.16 * *$ \\
Number of Branches & $0.73 * *$ \\
Stem diameter $(\mathrm{cm})$ & $0.22 *$ \\
Flower initiation (days) & $0.61 \mathrm{~ns}$ \\
Number of flowers & $21.98 * *$ \\
Flower diameter $(\mathrm{cm})$ & $0.17 * *$ \\
Information: $* * \quad=$ Significantly different at the $1 \%$ level of probability $(\mathrm{P}<0,01) ;$ \\
$\quad=$ Significantly different at the $5 \%$ level of probability $(\mathrm{P}<0,05) ;$ \\
$\mathrm{ns} \quad=$ Not significantly different at the $5 \%$ level of probability $(\mathrm{P}>0,05)$
\end{tabular}

Further tests of the parameters showed that in general the plant height, number of internodes, number of branches, and the stem diameter were performed better at $100 . \mathrm{mL}^{-1}$ of LOF. LOF Bio-urine treatment gave significant effects on all parameters of the vegetative component of potted chrysanthemum. Increasing LOF Bio-urine concentration resulted in higher the plant height, number of internodes, number of branches, and the stem diameter. Optimum results were obtained with a concentration of LOF Biourine $100 \mathrm{ml} / \mathrm{L}$. Nutrient content in biourine is easily absorbed by plants and quickly shows results is an alternative that can be used in chrysanthemum cultivation [4].

Tabel 2. Growth response of potted chrysanthemum of Armita variety to LOF bio-urine concentrations.

\begin{tabular}{cllllllll}
\hline \multirow{2}{*}{$\begin{array}{c}\text { Bio-urine } \\
\text { consentrations }\end{array}$} & \multicolumn{2}{c}{ Plant height } & \multicolumn{2}{c}{$\begin{array}{c}\text { Number of } \\
\text { internodes }\end{array}$} & $\begin{array}{c}\text { Number of } \\
\text { Branches }\end{array}$ & \multicolumn{2}{c}{ Stem diameter } \\
\cline { 2 - 9 } & \multicolumn{2}{c}{ cm } & \multicolumn{2}{c}{ nodes } & branches & \multicolumn{2}{c}{ cm } \\
\hline $200 \mathrm{ml} \mathrm{L}^{-1}$ & 12.72 & $\mathrm{~b}$ & 11.77 & $\mathrm{~b}$ & 2.58 & $\mathrm{c}$ & 2.12 & $\mathrm{~b}$ \\
$100 \mathrm{ml} \mathrm{L}^{-1}$ & 14.99 & $\mathrm{ab}$ & 14.31 & $\mathrm{a}$ & 3.64 & $\mathrm{a}$ & 2.68 & $\mathrm{a}$ \\
$66.67 \mathrm{ml} \mathrm{L}^{-1}$ & 15.12 & $\mathrm{a}$ & 14.16 & $\mathrm{ab}$ & 3.25 & $\mathrm{~b}$ & 2.42 & $\mathrm{ab}$ \\
$50 \mathrm{ml} \mathrm{L}^{-1}$ & 14.96 & $\mathrm{ab}$ & 13.29 & $\mathrm{ab}$ & 3.15 & $\mathrm{~b}$ & 2.41 & $\mathrm{ab}$ \\
$40 \mathrm{ml} \mathrm{L}^{-1}$ & 14.93 & $\mathrm{ab}$ & 13.13 & $\mathrm{ab}$ & 3.05 & $\mathrm{~b}$ & 2.56 & $\mathrm{a}$ \\
\hline $\mathrm{CV}(\%)$ & 4 & & 6 & & 6 & & 10 & \\
\hline
\end{tabular}

Information: In a column, means followed by the same letter are not significantly different at the $5 \%$ level of DMRT.

Insignificant results in treatments II, III, IV, and V indicated a significant loss of liquid organic fertilizer by evaporation. According to Lingga and Marsono [9] stated that the nutrient content in livestock urine quickly evaporates and is lost. In line with [4], liquid biourine causes a higher loss rate. Lower results in treatment I with a concentration of $200 \mathrm{ml} / \mathrm{L}^{-}$ 1 indicated excess/overdose in the use of LOF Bio-urine. Over-application of nutrients to plants has an adverse effect on their growth. According to Sarif et al. [10] stated that overapplication of nitrogen nutrients results in soft and weak shoots, lowers soil $\mathrm{pH}$, binds other nutrients. The fertilization given is not effective nor efficient.

Table 3. shows that the LOF Bio-urine concentration treatment gave significant results on the yield components of flower number and flower diameter, but not significant on flower initiation parameter. The initiation of chrysanthemum flowers is more influenced by the light factor. According to Mufarrikha et al. [11] stated that the addition of light to the chrysanthemum caused the vegetative phase to be longer so that the flower initiation was longer. 
Table 3. Flower initiation, number of flowers, and flower diameter of potted chrysanthemum Armita varieties at different concentrations of LOF Bio-urine

\begin{tabular}{|c|c|c|c|c|}
\hline $\begin{array}{c}\text { Bio-urine } \\
\text { consentrations }\end{array}$ & $\begin{array}{c}\text { Flower's initiation } \\
\text { days }\end{array}$ & $\begin{array}{c}\text { Number of flowers } \\
\text { pcs }\end{array}$ & $\begin{array}{r}\text { Flower's } \\
\text { c }\end{array}$ & $\begin{array}{l}\text { diameter } \\
\text { n }\end{array}$ \\
\hline $200 \mathrm{ml} \mathrm{L}^{-1}$ & 64.3 & $4.35 \mathrm{~b}$ & 3.61 & $\mathrm{c}$ \\
\hline $100 \mathrm{ml} \mathrm{L}^{-1}$ & 63.9 & 9.27 & 4.14 & $\mathrm{a}$ \\
\hline $66.67 \mathrm{ml} \mathrm{L}^{-1}$ & 64.4 & 9.41 & 3.98 & $a b$ \\
\hline $50 \mathrm{ml} \mathrm{L}^{-1}$ & 63.6 & 8.72 & 3.89 & $\mathrm{~b}$ \\
\hline $40 \mathrm{ml} \mathrm{L}^{-1}$ & 64.4 & 8.35 & 3.82 & $\mathrm{~b}$ \\
\hline CV (\%) & 1 & 21 & 4 & \\
\hline
\end{tabular}

The results obtained at harvest reflect the conditions in the vegetative stage. Good conditions in the vegetative phase are in line with the results obtained at harvest. The highest number of flowers was obtained in treatment III but did not significantly from treatment II, $\mathrm{IV}$, and $\mathrm{V}$. The total flowers produced are nine flowers/plant, equivalent to 54 flowers/pot. This study showed that LOF bio-urine can be used as an alternative to fertilizer because the number of flowers produced follows the quality standard criteria for potted chrysanthemumsAccording to Sari [12] stated that the number of flowers for grade A spray-potted chrysanthemum plants is 50-60 flowers/pot.

The largest flower diameter obtained in treatment II was $4.14 \mathrm{~cm}$ but did not differ significantly from treatment III and IV. LOF Bio-urine application can provide nutrient needs, so that potted chrysanthemum plants can grow according to standards. The potted chrysanthemum of the Armita variety belongs to the category of medium flowers with a flower diameter of $4 \mathrm{~cm} \mathrm{[13].} \mathrm{The} \mathrm{use} \mathrm{of} \mathrm{LOF} \mathrm{Bio-urine} \mathrm{with} \mathrm{a} \mathrm{concentration} \mathrm{of} 100 \mathrm{ml} \mathrm{L}^{-1}$ makes the agronomic appearance of chrysanthemum more optimal in several parameters.

\section{Conclusion}

The use of Bio-urine Liquid Organic Fertilizer shows a significant response to potted chrysanthemums. Bio-urine Liquid Organic Fertilizer with a concentration of $100 \mathrm{ml} \mathrm{L}^{-1}$ of water produces potted chrysanthemum with optimum plant height, number of internodes, number of branches, stem diameter, number of flowers, and flower diameter.

\section{References}

1. Statistics Indonesia, Production of Indonesian ornamental floriculture plants (BPS, 2019)

2. U. Suwahyono, Practical Instructions for Using Organic Fertilizers Effectively and Efficiently (Penebar Swadaya, Jakarta, 2011)

3. Putra, M.F.D. Maghfoer, Koesriharti, J. Prod. Tan. 5, 4 (2017)

4. E.D.S. Nugroho, D. Histifarina, A. Elonard, J. Agroekotek. 11, 1 (2019)

5. M.R. Sitorus, T. Irmansyah, F.E.T. Sitepu, J. Agroteknologi 3, 4 (2015)

6. A. Nurawan, D. Histifarina, Assessment of the Use of Biourine on the Growth of Chrysanthemum Flowers (Dendranthema grandiflora Tzvelev), in Proceeding of National Congress on Agricultural Resource Readiness and Site-Specific Innovation Entering the Industrial Era 4.0 (2020)

7. H. Rinanto, N. Azizah, M. Santosa, J. Prod. Tan. 3, 7 (2015)

8. IAARD. Potted Chrysanthemum Cultivations. Leaflet (unpublished) 
9. P. Lingga, Marsono, Instructions for Use of Fertilizer (Penebar Swadaya, Jakarta, 2013)

10. P. Sarif, A. Hadid, I. Wahyudi, e-J. Agrotekbis. 3, 5 (2015)

11. L. Mufarrikha, N. Herlina, E. Widaryanto, J. Prod. Tan. 2, 1 (2014)

12. A.N. Sari, Achievement of Quality Standards and Production Quality of Potted Chrysanthemum Flower (Dendranthema grandiflora Tzvelev Syn.) at PT. Saung Mirwan (Thesis, Institut Pertanian Bogor, 2010)

13. Nurmalinda, N.Q. Hayati, J. Hort. 24, 4 (2014) 